\title{
Mowing Wyoming Big Sagebrush Communities With Degraded Herbaceous Understories: Has a Threshold Been Crossed?
}

\author{
Kirk W. Davies, ${ }^{1}$ Jonathan D. Bates, ${ }^{1}$ and Aleta M. Nafus ${ }^{2}$ \\ Authors are ${ }^{1}$ Rangeland Scientist, USDA-ARS Eastern Oregon Agricultural Research Center, Burns, OR 97720, USA; and ${ }^{2}$ Research Associate, Oregon \\ State University, Corvallis, OR 97331, USA.
}

\begin{abstract}
Wyoming big sagebrush (Artemisia tridentata ssp. wyomingensis [Beetle \& A. Young] S.L. Welsh) plant communities with degraded native herbaceous understories occupy vast expanses of the western United States. Restoring the native herbaceous understory in these communities is needed to provide higher-quality wildlife habitat, decrease the risk of exotic plant invasion, and increase forage for livestock. Though mowing is commonly applied in sagebrush communities with the objective of increasing native herbaceous vegetation, vegetation response to this treatment in degraded Wyoming big sagebrush communities is largely unknown. We compared mowed and untreated control plots in five Wyoming big sagebrush plant communities with degraded herbaceous understories in eastern Oregon for $3 \mathrm{yr}$ posttreatment. Native perennial herbaceous vegetation did not respond to mowing, but exotic annuals increased with mowing. Density of cheatgrass (Bromus tectorum L.), a problematic exotic annual grass, was 3.3-fold greater in the mowed than untreated control treatment in the third year posttreatment. Annual forb cover, largely consisting of exotic species, was 1.8 -fold greater in the mowed treatment compared to the untreated control in the third year posttreatment. Large perennial grass cover was not influenced by mowing and remained below $2 \%$. Mowing does not appear to promote native herbaceous vegetation in degraded Wyoming big sagebrush plant communities and may facilitate the conversion of shrublands to exotic annual grasslands. The results of this study suggest that mowing, as a standalone treatment, does not restore the herbaceous understory in degraded Wyoming big sagebrush plant communities. We recommend that mowing not be applied in Wyoming big sagebrush plant communities with degraded understories without additional treatments to limit exotic annuals and promote perennial herbaceous vegetation.
\end{abstract}

\section{Resumen}

Las comunidades de plantas de artemisia Wyoming big sagebrush (Artemisia tridentata ssp. wyomingensis [Beetle \& A. Young] S.L. Welsh) con degradadas coberturas herbáceas ocupan una gran extensión del oeste de los Estados Unidos. El restablecimiento de la cobertura herbácea nativa en estas comunidades es necesario para mejorar la calidad del hábitat para fauna silvestre, mitigar el riesgo de la invasión de plantas exóticas e incrementar la producción de forraje para ganado. A pesar de que comúnmente se hacen cortes en comunidades de artemisia con el objetivo de incrementar la vegetación nativa, se desconoce la respuesta de la vegetación al tratamiento en áreas con comunidades degradadas de Wyoming big sagebrush. Se compararon parcelas segadas y áreas control sin tratamientos en cinco comunidades de Wyoming big sagebrush con cobertura herbácea degradada en el este de Oregón durante tres años posteriores a la aplicación de los tratamientos. La vegetación perenne herbácea no respondió a la siega, pero las plantas exóticas anuales se incrementaron con esta práctica. La densidad de cheatgrass (Bromus tectorum L.), una especie problemática exótica fue tres veces mayor en áreas segadas que en áreas control sin tratamiento tres años después de la aplicación de los tratamientos. La cobertura herbácea anual en gran parte formada por especies exóticas fue 1.8 veces mayor en las zonas segadas que en las áreas control sin tratamiento tres años posteriores a la aplicación de tratamientos. La gran cobertura de pastos perennes no fue influenciada por la siega y permaneció debajo del $2 \%$. La siega parece no promover la vegetación herbácea nativa en comunidades degradadas de Wyoming big sagebrush y podría facilitar el cambio de áreas de matorrales a pastizales anuales exóticos. Los resultados de este estudio sugieren que la siega, como un tratamiento independiente, no restablece la cobertura herbácea en comunidades de Wyoming big sagebrush. Nosotros recomendamos que la siega no se practique en comunidades de Wyoming big sagebrush con cobertura degradada sin tratamientos adicionales para limitar la presencia de plantas anuales exóticas y estimular la vegetación herbácea perenne.

Key Words: annual grass, Artemisia tridentata, brush control, brush management, cheatgrass, invasion, restoration

\section{INTRODUCTION}

Wyoming big sagebrush (Artemisia tridentata ssp. wyomingensis [Beetle \& A. Young] S.L. Welsh) plant communities occupy vast portions of the western United States (Miller et al. 1994; West and Young 2000). These plant communities provide an

Correspondence: Kirk Davies, USDA-ARS Eastern Oregon Agricultural Research Center, 67826-A Hwy 205, Burns, OR 97720. Email: kirk.davies@oregonstate.edu

Manuscript received 21 February 2012; manuscript accepted 18 June 2012. important forage base for livestock production and critical habitat for wildlife (Connelly et al. 2000; Crawford et al. 2004; Davies et al. 2006; Davies et al. 2009a). A decrease in fire frequency and historic overgrazing by sheep, cattle, and horses associated with European settlement degraded the native herbaceous understory (large reductions in large native perennial grass and forb abundance and production compared to reference sites) and increased sagebrush dominance in many locations (West 1983; Miller and Rose 1999). West (2000) 
estimated that $25 \%$ of the big sagebrush ecosystem is comprised of dense sagebrush stands with depleted native understories. West (2000) grouped all the subspecies of big sagebrush in this estimate. The percent of Wyoming big sagebrush plant communities with degraded understories is probably much greater because they are the most easily degraded of the three common big sagebrush subspecies (Miller and Eddleman 2000). Thus, large areas of Wyoming big sagebrush plant communities probably require active management to increase their native herbaceous understories.

Treatments that reduce sagebrush are often applied in big sagebrush communities in an attempt to restore the native herbaceous understory. Sagebrush control is expected to promote native herbaceous vegetation, because sagebrush competes with herbaceous vegetation for resources (Robertson 1947; Cook and Lewis 1963; Williams et al. 1991) and sagebrush control often generates two- to threefold increases in herbaceous vegetation (Mueggler and Blaisdell 1958; Hedrick et al. 1966; McDaniel et al. 1991; Davies et al. 2007; Davies et al. 2012). However, herbaceous vegetation does not always increase with sagebrush control (Blaisdell 1953; Peek et al. 1979; Sturges 1986). In addition, increases in herbaceous vegetation may be primarily exotic annuals. For example, exotic annual grasses have been reported to increase following fires in Wyoming big sagebrush plant communities (Stewart and Hull 1949; Young and Allen 1997; Davies et al. 2009b). However, Davies et al. (2011a) reported mowing Wyoming big sagebrush plant communities with relatively intact herbaceous understories caused only small increases in exotic annual grasses. Thus, applying mowing treatments in degraded Wyoming big sagebrush communities may not cause large increases in exotic annual species; however, this has not been tested.

Mowing is commonly applied in sagebrush plant communities to reduce sagebrush and increase herbaceous vegetation. However, empirical evidence of increases in native perennial herbaceous vegetation following mowing in Wyoming big sagebrush plant communities is generally lacking. The results of some studies suggest that there may be potential for perennial vegetation to increase with mowing in degraded Wyoming big sagebrush communities. For example, increases in native annual forbs and soil nutrient concentrations have been documented following mowing (Davies et al. 2011a). This suggests that mowing degraded Wyoming big sagebrush communities may increase resources for native perennial herbaceous vegetation. However, Davies et al. (2011a) did not observe an increase in native perennial grass or forbs cover, density, or biomass after mowing Wyoming big sagebrush plant communities. In contrast, in mountain big sagebrush plant (Artemisia tridentata spp. vaseyana [Rydb.] Beetle) communities, mowing generated a twofold increase in native perennial grass cover and biomass (Davies et al. 2012). The Wyoming (Davies et al. 2011a) and mountain (Davies et al. 2012) big sagebrush plant communities mowed in these studies had relatively intact native herbaceous understories and thus, in these situations, sagebrush may not have been a major factor limiting native herbaceous vegetation. Mountain big sagebrush plant communities are also more productive and diverse than Wyoming big sagebrush communities, and thereby may respond differently to disturbances (Davies and Bates 2010a, 2010b).
Though the goal of mowing Wyoming big sagebrush communities with degraded understories is to increase native herbaceous vegetation, results from the aforementioned studies suggest that there are probably two possible scenarios: 1) native herbaceous vegetation increases, or 2 ) exotic annual vegetation increases and native vegetation either remains relatively unchanged or decreases. It is important to know which of these possible outcomes occur with mowing because an increase in exotic annuals, especially exotic annual grasses, would negatively impact ecosystem function, degrade wildlife habitat, reduce quality livestock forage, and promote frequent wildfires that further degrade native plant communities (Mack 1981; D'Antonio and Vitousek 1992; Davies 2011). The large decline in the area occupied by the sagebrush ecosystem (Schroeder et al. 2004; Knick et al. 2003; Davies et al. 2011b) and the threat of these losses to sagebrush-associated wildlife (Connelly et al. 2000; Crawford et al. 2004) further emphasizes the need to determine the outcome of mowing Wyoming big sagebrush with degraded herbaceous understories.

The objective of this study was to determine the response of Wyoming big sagebrush plant communities with degraded herbaceous understories to mowing. We expected that sagebrush dominance limits the herbaceous understory and reduction via mowing leads to an increase in herbaceous vegetation. We evaluated if native herbaceous vegetation increased and/or if exotic annuals increased with mowing in degraded Wyoming big sagebrush plant communities.

\section{METHODS}

\section{Study Area}

The study was conducted at five sites in the High Desert Ecological Province (Anderson et al. 1998) in southeastern Oregon between 40 and $50 \mathrm{~km}$ southwest of Burns, Oregon, USA (lat $43^{\circ} 58^{\prime} \mathrm{N}$, long $119^{\circ} 02^{\prime} \mathrm{W}$ ). At all sites Wyoming big sagebrush was the dominant shrub and the herbaceous understory was considered degraded. Prior to treatment, cover of sagebrush, Sandberg bluegrass (Poa secunda J. Presl), large perennial bunchgrasses, and perennial forbs averaged across the study sites were $14.9 \%, 1.7 \%, 1.5 \%$, and $0.5 \%$, respectively. The perennial herbaceous component at our study sites were much lower than reported for relatively intact Wyoming big sagebrush communities in Davies et al. (2006) and (2010a). For example, large perennial grass cover was 5.9- to 6.7-fold greater in relatively intact Wyoming big sagebrush communities (Davies et al. 2006, 2010a) compared to our study sites. Sagebrush cover was 1.2- to 1.5 -fold greater at our study sites than the average reported for relatively intact Wyoming big sagebrush communities (Davies et al. 2006, 2010a). Sandberg bluegrass and squirreltail (Elymus elymoides [Raf.] Swezey) were the most common perennial grasses at the study sites. Bluebunch wheatgrass (Pseudoroegneria spicata [Pursh] A. Löve) and/or Thurber's needlegrass (Achnatherum thurberianum [Piper] Barkworth) were also found at the study sites and would have been the dominant perennial bunchgrasses if the plant communities were not degraded. Climatic conditions across the study area are characteristic of the High Desert Ecological Province with cool, wet winters and springs and hot, dry summers. Average 
annual precipitation ranges between 250 and $275 \mathrm{~mm}$ for the study area (Oregon Climatic Service 2009). Crop-year (1 October-30 September) precipitation was $87 \%, 101 \%$, and $118 \%$ of this long-term average in 2009, 2010, and 2011, respectively (Eastern Oregon Agricultural Research Center 2011). Elevation of the study sites ranged from 1263 to 1350 $\mathrm{m}$ above sea level and slopes were relatively flat $(0-4 \%)$. Soils at the study sites were loamy and well drained. Soil depth ranged from 50 to $100 \mathrm{~cm}$ to a duripan. All study sites were on the Loamy 10-12PZ (R023XY212OR) ecological site. Historical livestock use of this area was heavy and often season-long. Recent use was approximately $40 \%$ use of available forage, and season of use has been rotational. Livestock were excluded from the study sites during the experiment.

\section{Experimental Design and Measurements}

A randomized complete block design was used to determine the response of Wyoming big sagebrush plant communities with degraded understories to mowing. Five sites were used as blocks in this study. Blocks varied in soil characteristics and elevation. Each block consisted of two $30 \times 50-\mathrm{m}$ plots with a $2-\mathrm{m}$ buffer between plots and treatments were randomly assigned to one of the plots. Treatments were 1) mowed and 2 ) an untreated control. Mowing was implemented with a Schulte XH 1500 rotary cutter (Schulte Equipment Co., Englefield, Saskatchewan, Canada). Mowed plots were mowed to a 20-cm height in September of 2008. Prior to mowing, vegetation characteristics were similar between plots in each block, but varied between blocks.

Vegetation response variables were measured in June of 2009, 2010, and 2011. Four 50-m transects spaced $5 \mathrm{~m}$ apart were used to sample each $30 \times 50$-m plot. Shrub canopy cover by species was measured with the use of the line-intercept method (Canfield 1941) on each of the four transects. Shrub density was measured by species by counting all individuals rooted in four, $2 \times 50-\mathrm{m}$ belt transects. Each belt transect was positioned over one of the four $50-\mathrm{m}$ transects. Herbaceous canopy cover was estimated by species inside $40 \times 50-\mathrm{cm}$ frames $\left(0.2 \mathrm{~m}^{2}\right)$ located at 3-m intervals on each transect line (starting at $3 \mathrm{~m}$ ), resulting in 15 frames per transect and 60 frames per plot. Visual cover estimates were based on markings that divided the frames into $1,5,10,25$, and $50 \%$ segments. Moss and litter cover were also visual estimated in the $40 \times 50$ $\mathrm{cm}$ frames. Herbaceous density by species was also measured inside the $60,40 \times 50 \mathrm{~cm}$ frames.

\section{Statistical Analyses}

We used a mixed model of analysis of variance (ANOVA) in Spotfire S+ (Timco Software, Inc., Palo Alto, CA) to compare vegetation response variables between treatments in each year. For analyses, herbaceous cover and density were grouped into five functional groups: Sandberg bluegrass, large perennial bunchgrass, cheatgrass (Bromus tectorum L.), perennial forbs, and annual forbs. Sandberg bluegrass was treated as a separate functional group from the other perennial grasses because it is smaller in size and its phenological development generally occurs earlier than other perennial bunchgrasses
(James et al. 2008). Cheatgrass was the only annual grass detected at the study sites. Approximately $80 \%$ and $85 \%$ of the total annual forb cover and density was from desert madwort (Alyssum desertorum Stapf). No exotic perennial forbs or exotic perennial bunchgrasses were detected at any of the study sites. Shrub cover and density were separated into two groups: Wyoming big sagebrush and other shrubs. Wyoming big sagebrush was treated as a separate group because it was the dominant shrub and all the other shrubs were resprouters. Differences were considered significant at $P \leq 0.05$. Means were reported with standard errors (mean$\mathrm{SE})$.

\section{RESULTS}

Sandberg bluegrass, large perennial bunchgrass, and perennial forb cover did not differ between treatments in any year (Figs. 1A-1C; $P>0.05$ ). Annual forb and cheatgrass cover were greater in the mowed compared to the nontreated control in 2009, 2010, and 2011 (Figs. 1D and 1E; $P<0.05)$. Annual forb cover was 3.3-, 4.0-, and 1.8-fold greater in the mowed than control treatment in 2009, 2010, and 2011, respectively. Cheatgrass cover was 3.5-, 3.6-, and 4.6-fold greater in the mowed compared to the control in 2009, 2010, and 2011, respectively. Total herbaceous cover was 1.5-, 2.2-, and 1.4-fold greater in mowed compared to nontreated control in 2009, 2010, and 2011, respectively (Fig. 1F; $P<0.05$ ). Bare ground and sagebrush cover were less in the mowed compared to the nontreated control in all years (Figs. $2 \mathrm{~A}$ and $2 \mathrm{~B} ; \mathrm{P}<0.05$ ). Sagebrush cover was more than threefold greater in the nontreated control than the mowed treatment. Bare ground was 1.3-fold greater in the nontreated control compared to the mowed treatment in all years. Other shrub cover did not differ between treatments in any year of the study (Fig. 2C; $P>0.05$ ). Moss cover did not differ between treatments in 2009 (Fig. 2D; $P=0.15$ ). In 2010 and 2011, moss cover was lower in the mowed than nontreated control $(P=0.01$ and 0.02 , respectively). Litter cover was greater in the mowed compared to the control in all years $(P<0.05)$. Litter cover was $41 \pm 2,31 \pm 2$, and $32 \pm 2 \%$ in the mowed treatment and $28 \pm 1,24 \pm 3$, and $19 \pm 1 \%$ in the untreated control in 2009, 2010, and 2011, respectively.

Sandberg bluegrass, large perennial bunchgrass, and perennial forb density did not vary between treatments in 2009, 2010, and 2011 (Figs. 3A-3C; P>0.05). Annual forb density was 2.5-, 1.8-, 1.7-fold greater in the mowed compared to the nontreated control treatment in 2009, 2010, and 2011, respectively (Fig. 3D; $P<0.01$ ). Cheatgrass density did not differ between treatments in 2009 (Fig. 3E; $P=0.16$ ). In 2010 and 2011, cheatgrass density was 2.3- and 3.3 -fold greater in the mowed than control treatment, respectively $(P=0.03$ and 0.05 , respectively). Sagebrush density was more than 1.5 -fold greater in the nontreated control than the mowed treatment in all years of the study (Fig. 3F; $P<0.01$ ). Other shrub density did not differ between treatments in any of the years posttreatment (data not presented; $P>0.05$ ). 


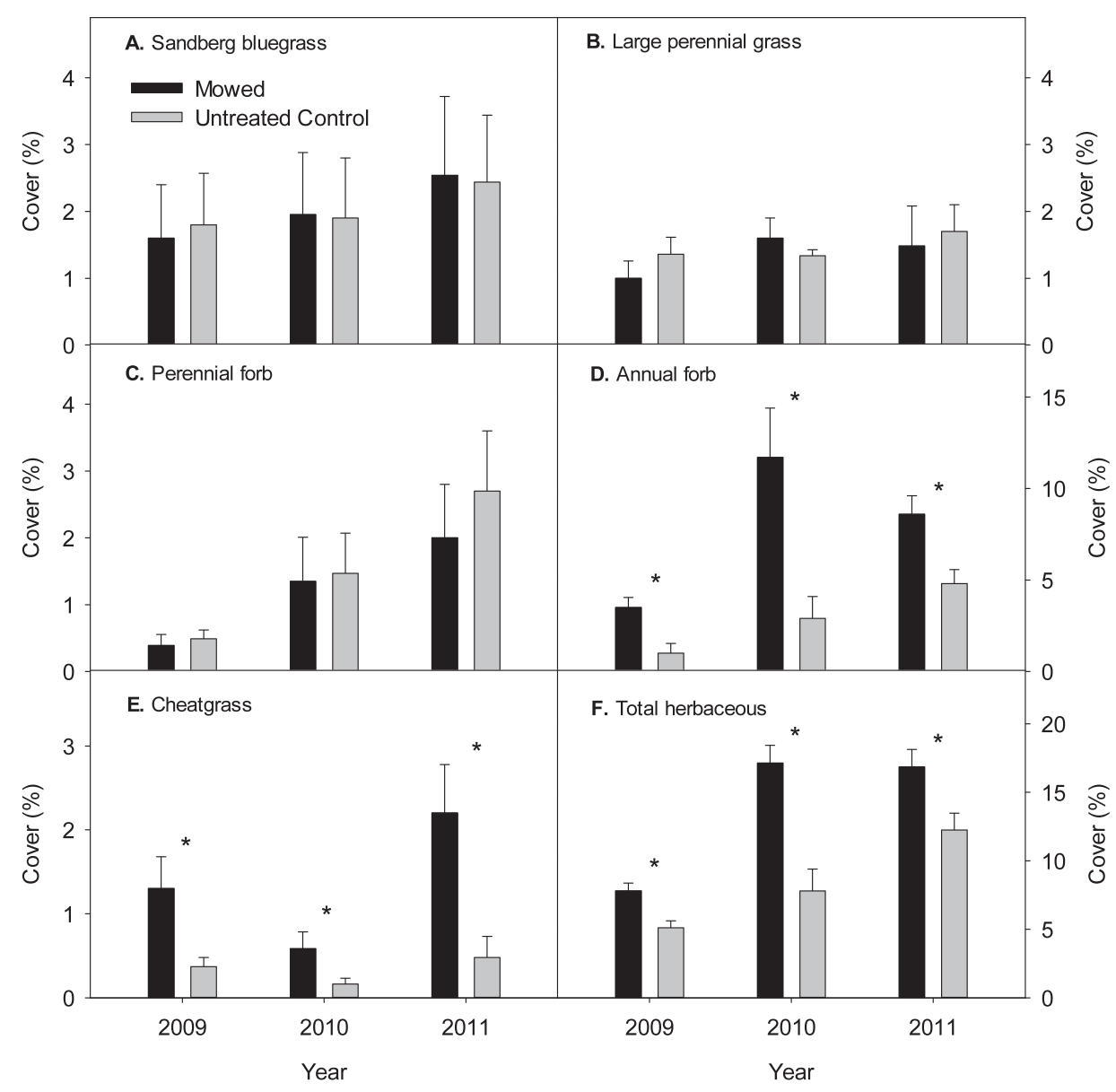

Figure 1. Plant functional group canopy cover (mean $+\mathrm{SE}$ ) in mowed and untreated control plots in Wyoming big sagebrush communities with degraded herbaceous understories in 2009, 2010, and 2011. An asterisk indicates significant $(P \leq 0.05)$ differences between treatments in that year. Note that scale varies by individual graph.

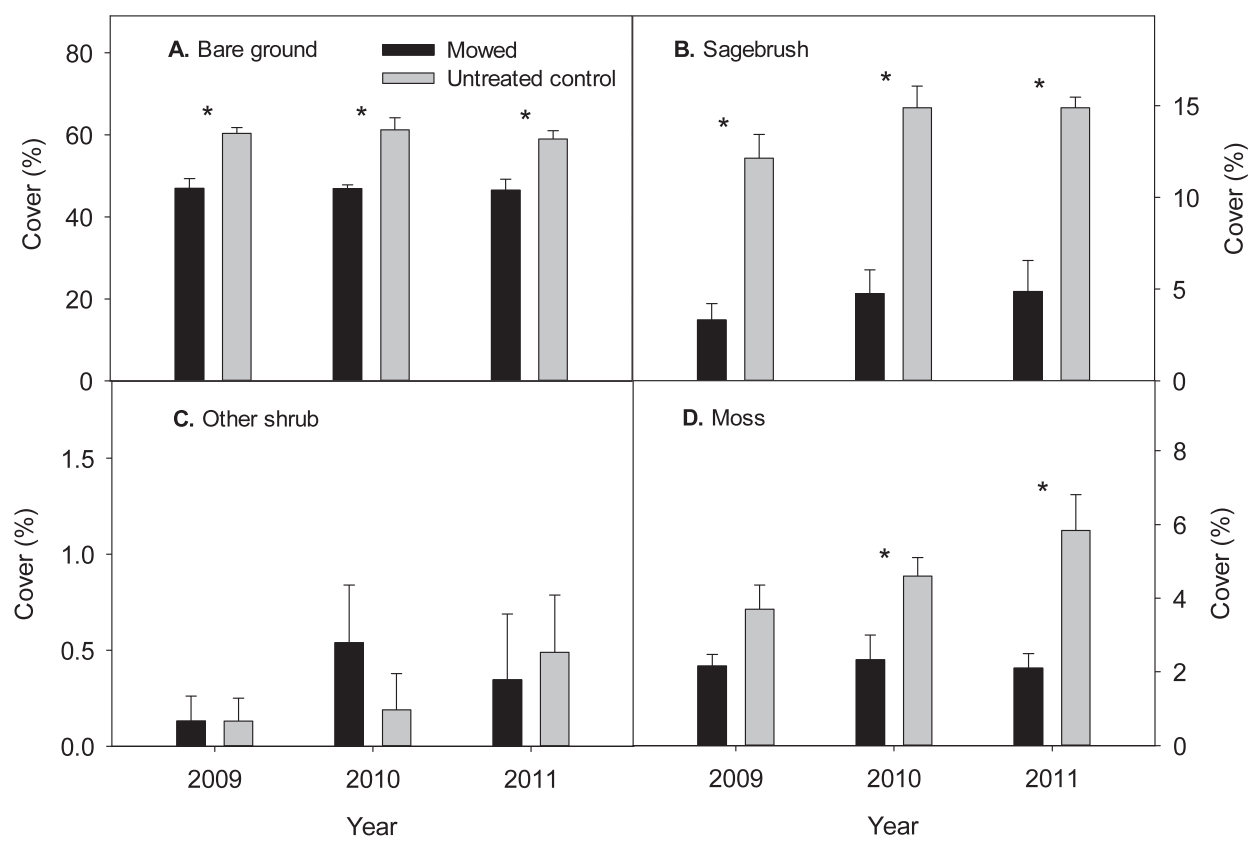

Figure 2. Shrub canopy cover, moss ground cover, and bare ground (mean $+\mathrm{SE}$ ) in mowed and untreated control plots in Wyoming big sagebrush communities with degraded herbaceous understories in 2009, 2010, and 2011. An asterisk indicates significant $(P \leq 0.05)$ differences between treatments in that year. Note that scale varies by individual graph. 


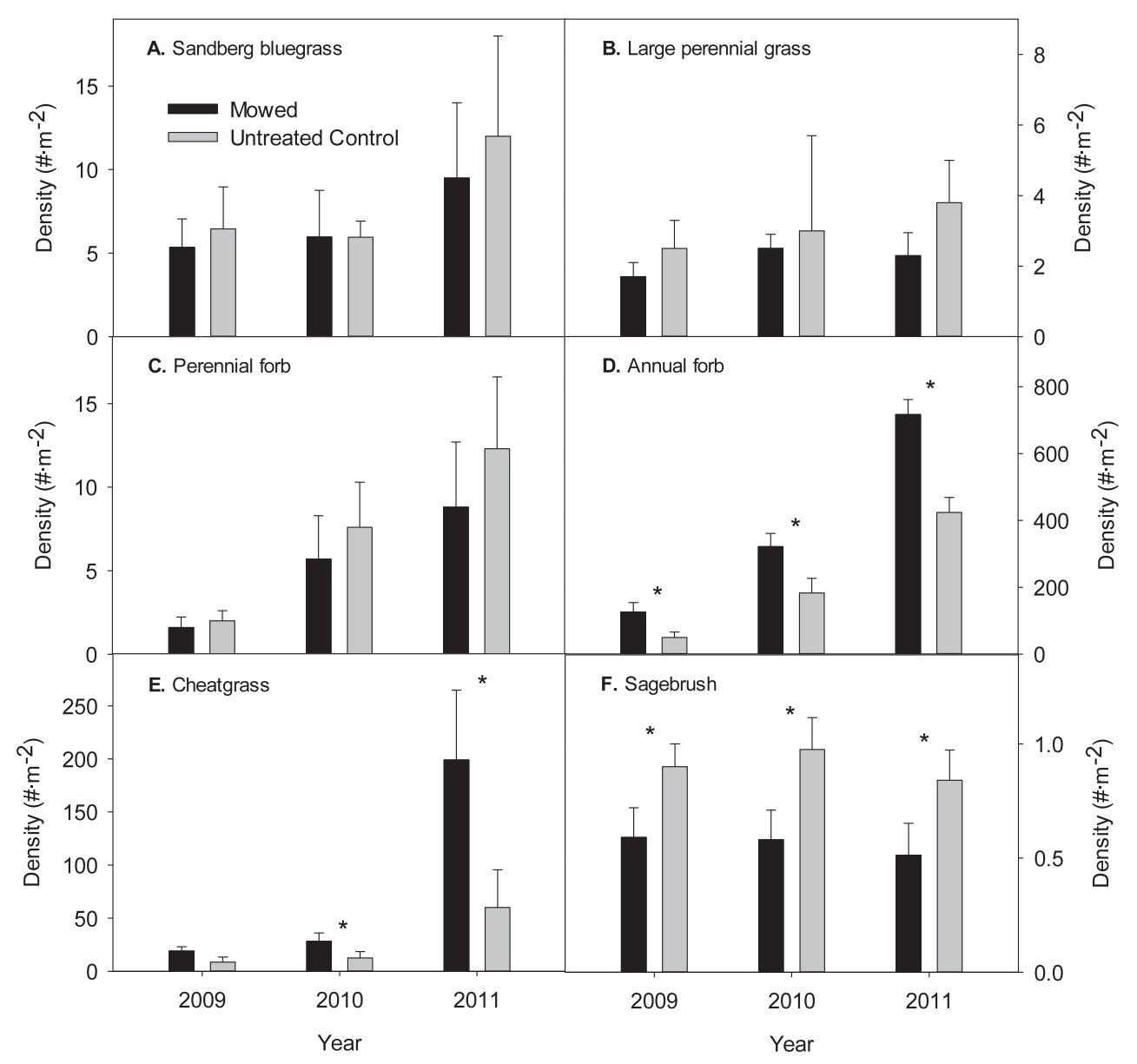

Figure 3. Plant functional group density (mean $+\mathrm{SE}$ ) in mowed and untreated control plots in Wyoming big sagebrush communities with degraded herbaceous understories in 2009, 2010, and 2011. An asterisk indicates significant $(P \leq 0.05)$ differences between treatments in that year. Note that scale varies by individual graph.

\section{DISCUSSION}

Though mowing Wyoming big sagebrush plant communities with degraded herbaceous understories increased total herbaceous vegetation, it did not elicit a positive response from native herbaceous vegetation and resulted in a decline in soil surface moss. The increase in exotic species after mowing these communities suggests a trajectory of continued degradation of the native plant community.

The results of this study indicate that sagebrush dominance is limiting herbaceous vegetation in degraded Wyoming big sagebrush communities. Total herbaceous cover was 1.4- to 2.2-fold greater where sagebrush was reduced with mowing. Similarly, other studies have reported two- and even threefold increases in herbaceous vegetation when sagebrush dominance is reduced (Mueggler and Blaisdell 1958; Hedrick et al. 1966; McDaniel et al. 1991; Davies et al. 2007; Davies et al. 2012). However, we found that exotic annual grasses and forbs appear best suited to take advantage of reductions in sagebrush in degraded Wyoming big sagebrush plant communities. Exotic annuals increased substantially with mowing the degraded Wyoming big sagebrush plant communities in our study. Mowing may favor exotic plants because it increases soil nutrient concentrations (Davies et al. 2011a). Greater water and soil nutrient availability have been repeatedly reported to increase the success of exotic plant invasions (Huenneke et al. 1990; Burke and Grime 1996; Davis et al. 2000). In addition, exotic annual grasses invading sagebrush communities are more able than native plants to take advantage of elevated soil nutrients (Young and Allen 1997; Vasquez et al. 2008).

Greater litter in the mowed treatment compared to the untreated control also probably favored exotic annual grasses. Litter moderates temperature and moisture, creating favorable microsites for germination and establishment of cheatgrass and other exotic annual grasses (Evans and Young 1970, 1972). Similarly, Japanese brome (Bromus japonicus Thunb.), an exotic annual grass, density was greater when litter covered the soil surface compared to bare ground and the importance of litter increased as precipitation decreased (Whisenant 1990). In our study, the approximate 1.5 -fold increase in litter with mowing probably greatly increased the number of favorable microsites for cheatgrass establishment. This combined with elevated resources probably facilitated greater density and cover of exotic annuals, especially cheatgrass, in the mowed treatment compared to the untreated control.

The lack of a native herbaceous vegetation response provides strong evidence that mowing Wyoming big sagebrush communities with degraded herbaceous understories will not restore the native herbaceous component; however, longer-term evaluation is needed. Similarly, mowing relatively intact 
Wyoming big sagebrush communities did not increase native perennial vegetation (Davies et al. 2011a). However, Davies et al. (2011a) reported that native annual forbs increase with mowing. We measured a large increase in annual forbs, but the increase was predominantly exotic species. More than $80 \%$ of the increases in annual forb cover and density were from desert madwort, an exotic annual forb. Though long-lived native perennial vegetation are often slow to respond in arid and semiarid environments (West et al. 1979; Neilson 1986; Liston et al. 2003), the average to above-average precipitation with wet, cool springs in the postmowing years should have been favorable climatic conditions for establishment of new individuals, especially native cool-season (C3) bunchgrasses. Therefore, it appears doubtful that native herbaceous vegetation will increase substantially in response to mowing. If exotic annuals had not increased, the response of native vegetation may have been different. Exotic annual species densities of almost 900 plant $\cdot \mathrm{m}^{-2}$ in the mowed areas probably severely limited the response of native herbaceous vegetation. Exotic annuals are competitive with native vegetation and may severely limit recruitment of native plants (Melgoza et al. 1990; Young and Mangold 2008). Native plant abundance and biodiversity declined exponentially with increasing abundance of an exotic annual grass (Davies 2011). Increases in exotic annuals probably suppress native vegetation in these ecosystems through competition and increased fire frequency (Hironaka and Sindelar 1975; D'Antonio and Vitousek 1992; Young and Mangold 2008; Davies 2011).

Increases in the cover and density of exotic annuals with mowing are concerning because the plant communities may have transitioned or may be transitioning across a threshold that will be prohibitively expensive and difficult to reverse. Invasion by exotic annual grasses, and possibly exotic annual forbs, may promote frequent fires by increasing fine fuel biomass and continuity. This may create an opportunity for an exotic annual species/fire cycle that would further degrade the native plant community and be difficult to reverse. For example, exotic annual grass invasion can promote frequent fires that are detrimental to native vegetation and facilitate annual grass invasion into adjacent noninvaded plant communities (D’Antonio and Vitousek 1992; Brooks et al. 2004). The increase in cover and density of exotic annual species in the mowed treatment in this study increased fine fuel continuity and probably the fine fuel biomass. Thus, mowing degraded Wyoming big sagebrush communities elevated the wildfire risk. The impact of increased exotic annual cover and density in these communities with mowing may take many years to be fully realized, especially because their full impacts may not be realized until they fuel frequent fire events.

Similar to the results of this study, Davies et al. (2011a) also reported that cheatgrass cover increased with mowing in relatively intact Wyoming big sagebrush plant communities. In the current study, however, we found a much greater increase in cheatgrass density and also an increase in exotic annual forb cover and density. This suggests that Wyoming big sagebrush plant communities with degraded herbaceous understories may be even more likely to respond negatively to mowing, at least without additional treatments, than relatively intact communities. Similarly, postfire exotic annual grass abundance in Wyoming big sagebrush plant communities depends to large degree on the herbaceous understory condition prefire. Burning degraded Wyoming big sagebrush plant communities resulted in large increases in exotic annual grasses (Stewart and Hull 1949; Young and Allen 1997), but burning Wyoming big sagebrush with intact herbaceous understory had limited exotic annual grass invasion (Davies et al. 2007; Bates et al. 2009). The combination of these results with our current results suggests that a threshold has been crossed when perennial native herbaceous vegetation is depleted in Wyoming big sagebrush communities. This threshold may be difficult and expensive to reverse. Thus, Wyoming big sagebrush communities with degraded herbaceous understories are likely less resilient to disturbance than ones with relatively intact herbaceous understories.

The decrease in moss with mowing is further evidence that mowing causes negative impacts in degraded Wyoming big sagebrush plant communities. Moss, as a major constituent of biological soil crusts, is a critical component of arid and semiarid ecosystems that captures resources, prevents erosion, and reduces invasibility (Belnap et al. 2001; Harper and Belnap 2001; Belnap 2006). Though biological soil crusts are not a large component of the cover in intact Wyoming big sagebrush plant communities in the northern Great Basin (Davies and Bates 2010a), a decrease in moss cover may have long-term negative impacts because surface moss in sagebrush plant communities is slow to recover from disturbances (Hilty et al. 2004). Similar to our results, Davies et al. (2011a) found that mowing relatively intact sagebrush communities reduced moss cover and attributed the decrease to soil surface disturbance from mowing and possibly the decline in sagebrush cover. Others have also linked disturbances to reductions in soil biotic crusts in the sagebrush steppe ecosystem (e.g., Ponzetti and McCune 2001; Ponzetti et al. 2007; Root and McCune 2012).

Though the goal of mowing was to increase native herbaceous vegetation by decreasing sagebrush, the decrease in sagebrush has some negative impacts that should be considered. Reducing sagebrush cover to less than $5 \%$ with mowing would negatively impact sagebrush obligate wildlife species if applied across large areas. For example, sage grouse (Centrocercus urophasianus) habitat needs (Connelly et al. 2000) would not be met with such low sagebrush cover after mowing (Hess and Beck 2012). Beck et al. (2012), in a synthesis of the literature, also concluded that mowing and other treatments that reduce sagebrush in Wyoming big sagebrush plant communities were generally not beneficial for sage grouse or common big-game ungulates. The reduction in sagebrush could also negatively impact other wildlife species, especially those that consume large quantities of sagebrush. For example, pygmy rabbits (Brachylagus idaboensis), pronghorn (Antilocapra americana), and mule deer (Odocoileus hemionus) consume, at least seasonally, large amounts of sagebrush (Mason 1952; Green and Flinders 1980; Austin and Urness 1983; Shipley et al. 2006). Thus, large-scale applications of treatments that greatly reduce sagebrush are not recommended in habitat for sagebrush-associated wildlife (Connelly et al. 2000; Wilson et al. 2011; Beck et al. 2012). The negative impact of mowing on sagebrush-associated wildlife habitat is expected to be finite, as sagebrush density and cover are predicted to recover in 10 and 19 years postmowing, 
respectively (Davies et al. 2009a). However, the increase in exotic annual species with mowing may promote frequent wildfires that will eliminate sagebrush from the plant communities. Thus, mowing degraded Wyoming big sagebrush stands would have at least short-term negative impacts to some sagebrush-associated wildlife species, but postmowing invasion of exotic annual species may permanently reduce available sagebrush habitat with the conversion to exotic annual communities that are maintained by an exotic species/fire cycle.

Though mowing degraded Wyoming big sagebrush communities promoted exotic annual dominance, doing nothing will probably also ultimately result in conversion to exotic annual communities. Fire is a natural disturbance in these ecosystems, so it is logical to assume that most degraded Wyoming big sagebrush communities will burn in a wildfire event at some point in time and the postburn communities will be dominated by exotic annuals (Stewart and Hull 1949; Chambers et al. 2007; Davies et al. 2011b). Reducing sagebrush dominance with mowing in Wyoming big sagebrush plant communities is not a method in and of itself to restore native herbaceous understories and increase resilience to disturbances. However, mowing may be a component of methods that include additional treatments (e.g., seeding, exotic annual control, etc.) to restore the herbaceous understories. This emphasizes the need for additional research on the interaction between mowing and other treatments to restore herbaceous understories and improve resilience in degraded Wyoming big sagebrush plant communities. Especially important would be research to determine if mowing promotes the establishment of seeded herbaceous vegetation and if mowing in combination with additional treatments can increase the resilience of plant communities to future disturbances.

\section{MANAGEMENT IMPLICATIONS}

Mowing Wyoming big sagebrush plant communities with degraded understories increased total herbaceous vegetation, but did not increase native perennial herbaceous vegetation. Mowing without additional treatments to promote native vegetation and control exotic species probably increases the risk of converting Wyoming big sagebrush plant communities to exotic annual-dominated communities. The increase in exotic annual species with mowing increased the cover of fine fuels which may elevate the wildfire risk. Degraded Wyoming big sagebrush plant communities should not be mowed without additional treatments planned to promote perennial herbaceous vegetation and control exotic annuals. This research suggests that Wyoming big sagebrush with degraded herbaceous understories have probably crossed a threshold that will be expensive and difficult to reverse. Thus, we caution against mowing Wyoming big sagebrush plant communities with degraded understories until research has determined the best treatment combinations to promote perennial herbaceous vegetation, limit exotic annuals, and increase resilience. In addition, we suggest that it is critical to prevent additional Wyoming big sagebrush communities from crossing the threshold from intact to degraded.

\section{ACKNOWLEDGMENTS}

We thank Brandi Carlon, Savannah Duff, Rodney Johnson, Julie Garner, and Sarah Fitzpatrick for assisting with data collection. We are also grateful to the Burns-District Bureau of Land Management for providing land for this research project. We also thank Rob Sharp with the Bureau of Land Management for his help in locating study sites. We appreciated reviews of earlier versions of this manuscript by Dr. Chad Boyd and Dr. Matt Madsen. Thoughtful reviews by the associate editor and anonymous reviewers were also greatly appreciated.

\section{LITERATURE CITED}

Anderson, E. W., M. M. Borman, And W. C. Krueger. 1998. The ecological provinces of Oregon: a treatise on the basic ecological geography of the state. Corvallis, $\mathrm{OR}$, USA: Oregon Agricultural Experiment Station. 138 p.

Austin, D. D., And P. J. Unness. 1983. Overwinter forage selection by mule deer on seeded big sagebrush-grass range. Journal of Wildlife Management 47:12031207.

Bates, J. D., E. C. Rhodes, K. W. Davies, and R. N. Sharp. 2009. Post-fire succession in big sagebrush steppe with livestock grazing. Rangeland Ecology \& Management 62:98-110.

Beck, J. L., J. W. Connelly, and C. L. Wambolt. 2012. Consequences of treating Wyoming big sagebrush to enhance wildlife habitats. Rangeland Ecology \& Management 65:444-455.

BELNAP, J. 2006. The potential roles of biological soil crusts in dryland hydrologic cycles. Hydrological Processes 20:3159-3178.

Belnap, J., R. Prasse, and K. T. Harper. 2001. Influence of biological soil crusts on soil environments and vascular plants. Ecological Studies 150:281-300.

BLAISDELL, J. P. 1953. Ecological effects of planned burning of sagebrush-grass range on the upper Snake River Plains. Washington, DC, USA: USDA. Technical Bulletin No. 1075. 34 p.

Brooks, M. L., C. M. D’Antonio, D. M. Richardson, J. B. Grace, J. E. Keeley, J. M. DiTomaso, R. J. Hobbs, M. Pellant, and D. Pyke. 2004. Effect of invasive alien plants on fire regimes. BioScience 54:677-688.

BuRKE, M. J. W., AND J. P. Grime. 1996. An experimental study of plant community invasibility. Ecology 77:776-790.

Canfield, R. H. 1941. Application of the line interception method in sampling range vegetation. Journal of Forestry 39:388-394.

Chambers, J. C., R. A. Roundy, R. R. Blank, S. E. Meyer, and A. Whittaker. 2007. What makes Great Basin sagebrush ecosystems invasible by Bromus tectorum? Ecological Monographs 77:117-145.

Connelly, J. W., M. A. Schroeder, A. R. Sands, and C. E. Braun. 2000. Guidelines to manage sage grouse populations and their habitats. Wildlife Society Bulletin 28:967-985.

Cook, C. W. AND C. E. Lewis. 1963. Competition between big sagebrush and seeded grasses on foothill ranges in Utah. Journal of Range Management 16:245-250.

Crawford, J. A., R. A. Olson, N. E. West, J. C. Mosley, M. A. Schroeder, T. D. Whitson, R. F. Miller, M. A. Gregg, and C. S. Boyd. 2004. Ecology and management of sage-grouse and sage-grouse habitat. Journal of Range Management 57:2-19.

D'Antonio, C. M., And P. M. Vitousek. 1992. Biological invasions by exotic grasses, the grass/fire cycle, and global change. Annual Review of Ecology and Systematics 23:63-87.

Davis, M. A., J. P. Grime, and K. Thompson. 2000. Fluctuating resources in plant communities: a general theory of invasibility. Journal of Ecology 88:528-534.

DaviES, K. W. 2011. Plant community diversity and native plant abundance decline with increasing abundance of an exotic annual grass. Oecologia 167:481-491.

DaVIES, K. W., AND J. D. Bates. 2010a. Vegetation characteristics of mountain and Wyoming big sagebrush plant communities in the northern Great Basin. Rangeland Ecology \& Management 63:461-466.

DaviES, K. W., AND J. D. Bates. 2010b. Native perennial forb variation between mountain big sagebrush and Wyoming big sagebrush plant communities. Environmental Management 46:452-458. 
Davies, K. W., J. D. Bates, D. D. Johnson, and A. M. Nafus. 2009a. Influence of mowing Artemisia tridentata ssp. wyomingensis on winter habitat for wildlife. Environmental Management 44:84-92.

Davies, K. W., J. D. Bates, and R. F. Miller. 2006. Vegetation characteristics across part of the Wyoming big sagebrush alliance. Rangeland Ecology \& Management 59:567-575.

Davies, K. W., J. D. Bates, and R. F. Miller. 2007. Short-term effects of burning Wyoming big sagebrush steppe in southeastern Oregon. Rangeland Ecology \& Management 60:515-522.

Davies, K. W., J. D. Bates, and A. M. Nafus. 2011a. Are there benefits to mowing intact Wyoming big sagebrush communities? An evaluation in southeastern Oregon. Environmental Management 48:539-546.

Davies, K. W., J. D. Bates, and A. M. Nafus. Vegetation response to mowing dense mountain big sagebrush stands. Rangeland Ecology \& Management 65:268276.

Davies, K. W., C. S. Boyd, J. L. Beck, J. D. Bates, T. J. Svejcar, and M. A. Gregg. 2011 b. Saving the sagebrush sea: an ecosystem conservation plan for big sagebrush plant communities. Biological Conservation 144:2573-2584.

Davies, K. W., T. J. Svejcar, and J. D. Bates. 2009b. Interaction of historical and nonhistorical disturbances maintains native plant communities. Ecological Applications 19:1536-1545.

Eastern Oregon Agricultural Research Center. 2011. Climatic dataset. Burns, OR, USA: Eastern Oregon Agricultural Research Center.

Evans, E. A., AND J. A. Young. 1970. Plant litter and establishment of alien annual weed species in rangeland communities. Weed Science 18:697-703.

Evans, E. A., AND J. A. Young. 1972. Microsite requirements for establishment of annual rangeland weeds. Weed Science 20:350-356.

GREen, J. S., AND J. T. Flinders. 1980. Habitat and dietary relationships of the pygmy rabbit. Journal of Range Management 33:136-142.

Harper, K. T., AND J. Belnap. 2001. The influence of biological soil crusts on mineral uptake by associated vascular plants. Journal of Arid Environments 47:347-357.

Hedrick, D. W., D. N. Hyder, F. A. Sneva, and C. E. Poulton. 1966. Ecological response of sagebrush-grass range in Central Oregon to mechanical and chemical removal of Artemisia. Ecology 47:432-439.

HeSS, J. E., AND J. L. BECK. 2012. Burning and mowing Wyoming big sagebrush: do treated sites meet minimum guidelines for greater sage-grouse breeding habitats? Wildlife Society Bulletin 36:85-93.

Hilty, J. H., D. J. Eldridge, R. Rosentreter, M. C. Wicklow-Howard, and M. Pellant. 2004. Recovery of biological soil crusts following wildfire in Idaho. Journal of Range Management 57:89-96.

Hironaka, M., AND B. W. SindelaR. 1975. Growth characteristics of squirreltail seedlings in competition with medusahead. Journal of Range Management 28:283-285.

Huenneke, L. F., S. P. Hamburg, R. K., H. A. Mooney, and P. M. Vitousek. 1990. Effects of soil resources on plant invasion and community structure in Californian serpentine grassland. Ecology 71:478-491.

James, J. J., K. W. Davies, R. L. Sheley, and Z. T. Aanderud. 2008. Linking nitrogen partitioning and species abundance to invasion resistance in the Great Basin. Oecologia 156:637-648.

Knick, S. T., D. S. Dobkin, J. T. Rotenberry, M. A. Schroeder, W. M. Vander Haegen, and C. V. RIPER. 2003. Teetering on the edge or too late? Conservation and research issues for avifauna of sagebrush habitats. Condor 105:611-634.

Liston, A., B. L. Wilson, W. A. Robinson, P. S. Doescher, N. R. Harris, and T. Svejcar. 2003. The relative importance of sexual reproduction versus clonal spread in an aridland bunchgrass. Oecologia 137:216-225.

Mack, R. N. 1981. Invasion of Bromus tectorum L. into western North America: an ecological chronicle. Agro-Ecosystems 7:145-165.

MASON, E. 1952. Food habits and measurements of Hart Mountain antelope. Journal of Wildlife Management 16:387-389.

Melgoza, G., R. S. Nowak, And R. J. Tausch. 1990. Soil water exploitation after fire: competition between Bromus tectorum (cheatgrass) and two native species. Oecologia 83:7-13.

MiLleR, R. F., AND L. L. EddLeman. 2000. Spatial and temporal changes of sage grouse habitat in the sagebrush biome. Corvallis, OR, USA: Oregon State University. Technical Bulletin 151. $35 \mathrm{p}$.

Millek, R. F., AND J. A. Rose. 1999. Fire history and western juniper encroachment in sagebrush steppe. Journal of Range Management 52:550-559.
Miller, R. F., T. J. Svejcar, and N. E. West. 1994. Implications of livestock grazing in the intermountain sagebrush region: plant composition. In: M. Vavra, W. A. Laycock, and R. D. Pieper [EDS.]. Ecological implications of livestock herbivory in the West. Denver, CO, USA: Society of Range Management. p. 101-146.

McDaniel, K. C., D. L. Anderson, and J. F. Ballientte. 1991. Wyoming big sagebrush control with metsulfuron and 2,4-D in northern New Mexico. Journal of Range Management 44:623-627.

Mueggler, W. F., And J. P. Blaisdell. 1958. Effects on associated species of burning, rotobeating, spraying, and railing sagebrush. Journal of Range Management 11:61-66.

Nellson, R. P. 1986. High-resolution climatic analysis and southwest biogeography. Science 232:27-34.

Oregon Climatic Service. 2009. Oregon Climatic Data. Available at: http://www.ocs. oregonstate.edu/index.html. Accessed 1 September 2009.

Peek, J. M., R. A. Riggs, and J. L. Lauer. 1979. Evaluation of fall burning on bighorn sheep winter range. Journal of Range Management 32:430-432.

PonzettI, J. M., And B. McCune. 2001. Biotic soil crusts of Oregon's shrub steppe: community composition in relation to soil chemistry, climate, and livestock activity. Bryologist 104:212-225.

Ponzetti, J. M., B. McCune, and D. Pyke. 2007. Biotic soil crusts in relation to topography, cheatgrass and fire in the Columbia Basin, Washington. Bryologist 110:706-722.

RoberTson, J. H. 1947. Response of range grasses to different intensities of competition with sagebrush (Artemisia tridentata Nutt.). Ecology 28:1-16.

Root, H. T., AND B. McCune. 2012. Regional patterns of biological soil crust lichen species composition related to vegetation, soils, and climate in Oregon, USA. Journal of Arid Environments 79:93-100.

Schroeder, M. A., C. L. Aldridge, A. D. Apa, J. R. Bohne, C. E. Braun, S. D. Bunnell, J. W. Connelly, P. A. Deibert, S. C. Gardner, M. A. Hilliard, G. D. Kobriger, S. M. McAdam, C. W. McCarthy, J. J. McCarthy, D. L. Mitchell, E. V. Rickerson, and S. J. Stiver. 2004. Distribution of sage-grouse in North America. Condor 106:363-376.

Shipley, L. A., T. B. Davila, N. J. Thines, and B. A. Elias. 2006. Nutritional requirements and diet choices of pygmy rabbit (Brachylagus idahoensis): a sagebrush specialist. Journal of Chemical Ecology 32:2455-2474.

Stewart, G., And A. C. Hull. 1949. Cheatgrass (Bromus tectorum L.)—an ecologic intruder in southern Idaho. Ecology 30:58-74.

StuRGES, D. L. 1986. Response of vegetation and ground cover to spraying a high elevation, big sagebrush watershed with 2, 4-D. Journal of Range Management 39:141-146.

Vasquez, E., R. Sheley, and T. Svejcar. 2008. Nitrogen enhances the competitive ability of cheatgrass (Bromus tectorum) relative to native grasses. Invasive Plant Science and Management 1:287-295.

WEST, N. E. 1983. Western Intermountain sagebrush steppe. In: N. E. West (ED.). Ecosystems of the world: temperate deserts and semideserts. Amsterdam, The Netherlands. Elsevier Scientific. p. 351-374.

WEST, N. E. 2000. Synecology and disturbance regimes of sagebrush steppe ecosystems. In: P. G. Entwistle, A. M. DeBolt, J. H. Kaltenecker, and K. Steenhof [EDS.]. Sagebrush steppe ecosystem symposium. Boise, ID, USA: Bureau of Land Management. p. 15-26.

West, N. E., K. H. Rea, and R. 0. Harris. 1979. Plant demographic studies in sagebrush-grass communities in southeastern Idaho. Ecology 60:376-388.

WESt, N. E., AND J. A. Young. 2000. Intermountain valleys and lower mountain slopes. In: M. G. Barbour and W. D. Billing [EDS.]. North American terrestrial vegetation. Cambridge, UK: Cambridge University Press. p. 255-284.

Willams, K., J. H. Richards, and M. M. Caldwell. 1991. Effect of competition on stable carbon isotope ratios of two tussock grass species. Oecologia 88:148-151.

WiLson, T. L., F. P. HowE, AND T. C. EdwardS, JR. 2011. Effects of sagebrush treatments on multi-scale resource selection by pygmy rabbits. Journal of Wildlife Management 75:393-398.

Whisenant, S. G. 1990. Postfire population dynamics of Bromus japonicus. American Midland Naturalist 123:301-308.

Young, J. A., AND F. L. Allen. 1997. Cheatgrass and range science: 1930-1950. Journal of Range Management 50:530-535.

Young, K., AND J. Mangold. 2008. Medusahead outperforms squirreltail through interference and growth rate. Invasive Plant Science and Management 1:73-81. 